\title{
LOCALLY DELIVERED LOVASTATIN-CONTAINING CHITOSAN NANOPARTICLES PROMOTE BONE REGENERATION IN RATS
}

\author{
O. O. SHEVCHUK ${ }^{1 \bowtie}$, Ya. V. PANASIUK ${ }^{2}$, M. M. KORDA ${ }^{3}$ \\ ${ }^{1}$ Department of Pharmacology and Clinical Pharmacology, \\ I. Horbachevsky Ternopil National Medical University, Ternopil, Ukraine; \\ ${ }^{2}$ Department of Functional and Laboratory Diagnostics, \\ I. Horbachevsky Ternopil National Medical University, Ternopil, Ukraine; \\ ${ }^{3}$ Department of Medical Biochemistry, I. Horbachevsky Ternopil National \\ Medical University, Ternopil, Ukraine; \\ 凶e-mail: shevchukoo@tdmu.edu.ua
}

Received: 24 February 2021; Accepted: 23 April 2021

\begin{abstract}
Hypolipidemic statins can stimulate osteoregeneration. However, such effects are observed only after administration methods that are unacceptable for patients (prolonged infusions or huge oral doses). The aim of our research was to compare the osteoregeneration effects of lovastatin administered alone as a common pharmaceutical formulation and as lovastatin-containing chitosan nanoparticles (LCCN) in a drill-hole model of bone damage in rats. White inbred rats were randomly divided into four groups: group 1 - intact rats; group 2 - rats with bone defect without treatment (control group); group 3 - rats with bone defect, which received common pharmaceutical formulation of lovastatin at doses of 0.1, 1.0 and $5.0 \mathrm{mg} / \mathrm{kg}$; group 4-rats, which received $0.1 \mathrm{mg} / \mathrm{kg}$ lovastatin in the form of lovastatin-containing chitosan nanoparticles (LCCN). A dental drill of $2.0 \mathrm{~mm}$ in diameter was used to form the tibial bone defect. Rats were sacrificed 3, 7, 14 and 28 days after bone defect formation. Calcium (Ca), phosphorus $(P)$ and sialic acid concentrations, alkaline and acidic phosphatase activities, mineralization index, and collagenolytic activity were measured in blood serum. Computed tomography (CT) and histological study were used to estimate the regenerative processes in the bone. It was found that therapeutic doses of lovastatin $(0.1$ and $1.0 \mathrm{mg} / \mathrm{kg})$ are ineffective for bone defect healing. Only high doses of lovastatin $(5.0 \mathrm{mg} / \mathrm{kg})$ promote osteoregeneration. LCCN were more efficient compared to lovastatin alone, as confirmed by CT examination of bone defects and significant changes of Ca, $P$, and sialic acid concentrations, alkaline and acidic phosphatase activities, mineralization index, and collagenolytic activity. Lovastatin-containing chitosan nanoparticles effectively enhance fracture healing in used preclinical model. This finding suggests the possibility that a similar approach may be effective in hastening fracture repair in humans.
\end{abstract}

Ke y w o rd s: chitosan nanoparticles, lovastatin, fracture, bone regeneration in rats.

\section{Introduction}

Bone defects are widespread and may be caused by trauma, surgery, some hereditary pathologies or infections [1]. There are three phases in the body's response to fractures: inflammation, renewal and remodeling, which involve cytokine cascade reactions, and innate and adaptive immune processes $[1,2]$. Primarily, catabolic processes dominate, then later the shift to the anabolic phase occurs to promote overall stability of the fixation and immobilization of the fracture $[1,3]$. The role of growth factors in regeneration is crucial, including bone morphogenic proteins (BMPs). The most studied members of this transforming growth factor-beta (TGF- $\beta$ ) superfamily are BMP-2, BMP-3, BMP-4 and BMP-7 [4, 5]. Despite the fact that BMP-2 could be the most effective for fracture healing [6], its administration is still questionable. Some clinical trials did not demonstrate any benefits of BMPs [7]. Also, BMP2 may produce side effects, namely severe edemas, 
undesirable ectopic bone formation, delayed bone formation and probably increased cancer risks [5] and is quite expensive [8].

Stimulation of bone regeneration by targeting molecular signaling pathways indirectly seems more promising. It was reported that the lipid-lowering statin drugs (e.g., lovastatin, pravastatin) could stimulate BMP-2 expression by bone cells and foster bone repair [9-11]. Statins block the activity of $\beta$-hydroxy $\beta$-methylglutaryl-CoA (HMG-CoA) reductase, also known as 3-hydroxy-3-methylglutarylCoA reductase, acting as a chemical analogue of substrate HMG-CoA and resulting in the upregulation of BMP-2 gene expression by decreasing protein prenylation of isoprenoids intermediates, such as farnesyl pyrophosphate and geranylgeranyl pyrophosphate [12, 13]. The inhibition of protein prenylation causes a reduction of transforming protein RhoA, which is a prenylated protein and results in the increase of BMP-2 gene expression. Hagihara et al. have also confirmed that the inhibition of RhoA was able to promote BMP-2 induced osteoblastic differentiation processes [14]. Moreover, the reduction of RhoA stimulates VEGF expression via the activation of the P13-Kinase/Akt pathway and upregulation of eNOS. In turn, VEGF promotes osteoblast differentiation and angiogenesis resulting in the stimulation of bone formation [15]. Previous reports show that statins can act both as bone anabolic and as anti-resorptive agents [16, 17].

However, the need for long duration intravenous infusions or administration of large oral doses of statins are not acceptable [18]. Thus, the search for an appropriate drug-delivery nanocarrier is a challenge for bone regeneration medicine. For our study we choose lovastatin, which was the first statin developed, and has few adverse effects compared to atorvastatin, simvastatin or rosuvastatin which demonstrate evident hepatotoxicity and myopathy in animal models [19-21]. The aim of our research was to compare the osteoregeneration effects of lovastatin administered alone as a common pharmaceutical formulation and as lovastatin-containing chitosan nanoparticles (LCCN) in a drill-hole model of bone damage in rats.

\section{Materials and Methods}

Three-month-old male Wistar rats weighing $200 \pm 20$ g were obtained from the Ternopil National Medical University (TNMU) laboratory animal resource unit. All rats were fed a standard diet and given ad libitum access to water. Animal investigations conformed to the European Convention for the Protection of Vertebrate Animals Used for Experimental and Other Scientific Purposes (Strasbourg, 1986). The study design was approved by the TNMU Ethical Committee, protocol No 41 from 1 June 2017.

Fabrication of LCCN. Chitosan nanoparticles were prepared according to the procedure reported by Wu et al. (2005) [22] based on the ionic gelation of chitosan with tripolyphosphate (TPP) anions. Chitosan (Sigma-Aldrich Co., St. Louis, Missouri, USA) solution ( $25 \mathrm{ml}, 0.2 \%$, w/v) was prepared in acetic acid (1\%, v/v) and incubated with $10 \mathrm{ml}$ of $50 \mathrm{mg} / \mathrm{ml}$ lovastatin (Sigma-Aldrich Co., USA) for $30 \mathrm{~min}$ at room temperature. LCCN were spontaneously formed by adding $10 \mathrm{ml}$ of TPP aqueous solution $(0.1 \% \mathrm{w} / \mathrm{v})$ to the reaction mixture in a dropwise manner under constant magnetic stirring at $700 \mathrm{rpm}$. Finally, the resulting LCCN were harvested by ultracentrifugation (28000 rpm/48000 g) for $30 \mathrm{~min}$, washed several times with saline and subsequently resuspended.

Measurement of LCCN size. The resulting LCCN obtained after ultracentrifugation were examined by transmission electron microscopy (TEM) using the morphometric program Video-test-5.0, Kappa Image Base (Sumy Electron Optics, Sumy, Ukraine). For TEM analysis, a drop of LCCN dispersion (in distilled water) was placed onto the copper microgrid that was natively stained by phosphotungstic acid and allowed to evaporate and dry at room temperature $\left(25 \pm 2^{\circ} \mathrm{C}\right)$. Subsequently, the dried microgrids were viewed at different resolutions. The manufactured nanoparticles ranged in size from 40-100 nm in diameter.

Measurement of lovastatin concentration. To determine the amount of lovastatin in LCCN the nanoparticles harvested by ultracentrifugation were completely degraded. LCCN degradation was performed as follows: nanoparticles were suspended in $\mathrm{HCl}(2.0 \mathrm{M})$ at $72^{\circ} \mathrm{C}$ for $3 \mathrm{~h}$ and ultrasonicated using ultrasonic dispersant USDN-M750T $(20-25 \mathrm{kHz}$, $750 \mathrm{~W}$ ) for $10 \mathrm{~min}$ [23]. Lovastatin content was determined by the dual-wavelength UV spectrophotometry method using Perkin Elmer Lambda 25 UV/ Vis spectrophotometer (Shelton, Connecticut, USA) [24]. Briefly, the spectrum of lovastatin was recorded in absorbance mode. The radiation source was a deuterium lamp emitting a continuous UV spectrum. The absorbencies at $246 \mathrm{~nm}$, which is the characteristic absorption peak of lovastatin, and at $254 \mathrm{~nm}$ 
were recorded and used to plot a calibration curve for calculating the UV spectrum lovastatin content. The lovastatin standard solution was prepared by dissolving an accurately weighed amount (3.2 mg) of lovastatin in $50 \mathrm{ml}$ of $75 \%$ ethanol. This stock solution was used to prepare working solutions by adding an appropriate volume of $75 \%$ ethanol. The calibration curve was constructed by recording the UV spectrum of solutions with final lovastatin concentrations 3.2, 6.4, 12.8, 19.2, 25.6, 32.0, 38.4, 44.8, 51.2 , and $57.6 \mathrm{mg} / \mathrm{ml}$. The absorbances of lovastatin at 246 and $254 \mathrm{~nm}$ were monitored separately, and the A246-A254 value was used to calculate the contents of lovastatin in samples.

In vivo rat bone defect model and treatments. Animals were randomized into 4 groups: $1^{\text {st }}$ group intact rats $(n=8)$; $2^{\text {nd }}$ group - rats with bone defect without treatment (control group) ( $n=32)$; $3^{\text {rd }}$ group rats with bone defect that received the common pharmaceutical formulation of lovastatin at doses of $0.1,1.0$ and $5.0 \mathrm{mg} / \mathrm{kg}(n=96)$; and $4^{\text {th }}$ group - rats that received $0.1 \mathrm{mg} / \mathrm{kg}$ of lovastatin in the form of
LCCN ( $n=32$ ) (Fig. 1). Intraperitoneal injection of $5 \mathrm{mg} / \mathrm{kg}$ ketamine was used to anesthetize the animals. The skin was shaved and scrubbed with an antiseptic solution ( $1 \%$ iodine). After exposing the right proximal tibia, a standardized $2.0 \mathrm{~mm}$ diameter noncritical bone defect was created by transosseous perforation using a motorized drill under irrigation with saline solution [25]. The procedures were tolerated without complications. Three, seven, fourteen and twenty-eight days after the bone defect formation, the rats were sacrificed (eight animals from each group for each time point) under thiopental-induced general anesthesia.

A $50 \mu \mathrm{l}$ volume of either lovastatin alone at doses of $0.1,1.0$ and $5.0 \mathrm{mg} / \mathrm{kg}$ [8] or LCCN $(0.1 \mathrm{mg} /$ $\mathrm{kg}$ of lovastatin) was injected directly into the bone defect site once daily throughout the entire experiment. All animals received analgesic meloxicam ( $2 \mathrm{mg} / \mathrm{kg}$ subcutaneously) and antibiotic ceftriaxone (30 $\mathrm{mg} / \mathrm{kg}$ intramuscularly) once daily for 3 days after bone defect formation to manage the postoperative pain and to prevent infectious complications

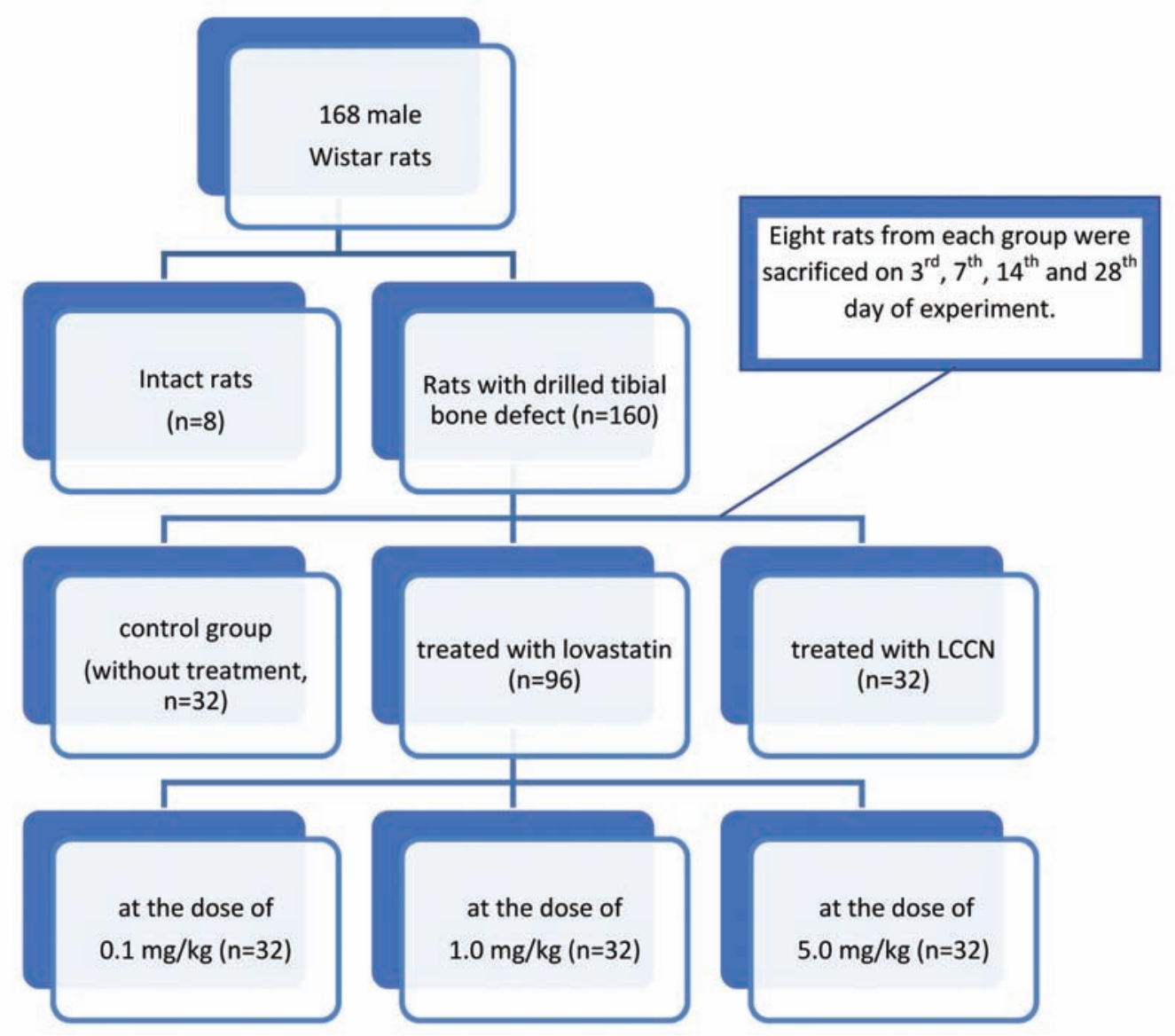

Fig. 1. Study design. LCCN - lovastatin-containing chitosan nanoparticles 
$[26,27]$. The health condition and behavior of the animals were observed daily after surgery until retrieving.

Sample collection. Blood was collected from the heart in terminal anesthesia through cardiac puncture. Blood was centrifuged for $10 \mathrm{~min}$ at $3000 \mathrm{rpm}$ and serum samples were stored at $-20^{\circ} \mathrm{C}$ until measurements were made.

Biochemical tests of bone metabolism. Calcium (Ca) and phosphorus (P) concentrations were measured photometrically using kits from PLIVALachema (Brno, Czech Republic). Alkaline phosphatase (ALP) and acidic phosphatase (ACP) activities were determined photometrically with assay kits from Human Diagnostics, (Darmstadt, Germany). The mineralization index (MI, units) was calculated as the ratio of ALP and ACP activities. To assess liver function, transaminases activity, alanine aminotransferase (ALT) and aspartate aminotransferase (AST), total bilirubin and serum total protein level were measured photometrically (with standard assay kits from Human Diagnostics (Darmstadt, Germany) and PLIVA-Lachema (Brno, Czech Republic) respectively). Collagenolytic activity and sialic acid content were determined spectrophotometrically according to methods described previously [28-30]. All measurements were performed on the Lambda 25 spectrophotometer (PerkinElmer, Inc., Shelton, Connecticut, USA).

Radiographic estimation of bone defect repair. The diameter of the bone defect was studied on the $14^{\text {th }}$ and $28^{\text {th }}$ days of the experiment by computer tomography (CT) examination. A Somatom Emotion 16-Slice (Munich, Germany) was used to image the bones. The bone mineral density and strength of the tibia area, as well as diameter of bone defect were estimated.

Histology of bone tissues. The harvested bones were dissected and fixed in $10 \%$ neutral buffered formalin solution for $48 \mathrm{~h}$, to free them from soft tissues with a decalcification procedure using $10 \%$ nitric acid solution for 30 days. The decalcified bones were then dehydrated in graded ethanol (70-100\%), cleared in xylene, embedded in paraffin, and finally, 8-10 $\mu \mathrm{m}$ thick sections were prepared and stained with hematoxylin and eosin (H\&E) and van Gieson stains. The histological sections were examined using a light microscope (Olympus BX51; Olympus, Tokyo, Japan) and blindly scored by two independent pathologists. The histopathological characteristics were evaluated in the tissue sections after H\&E and van Gieson staining on the $3^{\text {rd }}, 7^{\text {th }}, 14^{\text {th }}$ and $28^{\text {th }}$ days.
Statistical analysis. The data are presented as mean \pm SE (standard error). Statistical analysis was performed by the Statistica 10.0 program (StatSoft Inc., Tulsa, Oklahoma, USA). The distribution of indices was estimated using the Shapiro-Wilk normality test. Results of CT examination were analyzed using Kruskal-Wallis non-parametric test followed by Tukey post-hoc comparisons test. Data of biochemical analyses were analyzed using repeated measures non-parametric ANOVA test for multiple comparisons. A probability level of less than 0.05 was considered as statistically significant.

\section{Results and Discussion}

The most common biomarkers of bone metabolism are byproducts produced from the bone remodeling process. All of them can be classified as either markers of bone formation (e.g., ALP, procollagen type $1 \mathrm{~N}$-terminal propeptide (P1NP), osteocalcin) or as markers of bone resorption (e.g., hydroxyproline, ACP) [31-33].

No infection or any other adverse reactions at the operative site or throughout the body was observed following the drilled bone defect during the experiment period. The biochemistry examination revealed that there were no significant differences in the ALT and AST activities and total bilirubin or serum total protein levels between any of the test groups and the control group as well as the intact rat group (data not shown). These findings demonstrated the absence of hepatotoxicity signs.

Ca concentration in the serum of intact rats was $2.23 \pm 0.13 \mathrm{mmol} / \mathrm{l}$. Bone defect caused an increase of the Ca concentration on the $3^{\text {rd }}$ day compared to intact rats: in the control group by 56.0\% $(P<0.05)$, in the experimental $0.1 \mathrm{mg} / \mathrm{kg}$ lovastatin group by $52.9 \%$, the $1.0 \mathrm{mg} / \mathrm{kg}$ group by $65.9 \%$, the $5.0 \mathrm{mg} /$ $\mathrm{kg}$ group by $61.9 \%(P<0.05$ in all cases) and in the LCCN group by $43.9 \%(P<0.05)$. There were no significant differences in serum $\mathrm{Ca}$ concentrations between rats with untreated bone defect and rats treated with different doses and pharmaceutical formulations of lovastatin. There was only a significant difference in the serum Ca concentration on the $7^{\text {th }}$ day between the group of animals treated with LCCN and rats treated with lovastatin alone at the dose of $5.0 \mathrm{mg} / \mathrm{kg}$ (Table 1). Ca level was normalized on the $14^{\text {th }}$ day in all groups except in rats which received lovastatin at the dose of $0.1 \mathrm{mg} / \mathrm{kg}$.

We observed the same tendency for the P concentration in serum (Table 2), which is expected be- 
Ta ble 1. Calcium concentration in serum of rats with bone defect and correction with lovastatin alone or $\operatorname{LCCN}(M \pm m)$

\begin{tabular}{l|c|c|c|c}
\hline \multirow{2}{*}{\multicolumn{1}{c|}{ Group }} & \multicolumn{4}{c}{ Day of experiment } \\
\cline { 2 - 5 } & $3^{\text {rd }}$ & $7^{\text {th }}$ & $14^{\text {th }}$ & $28^{\text {th }}$ \\
\hline Intact rats $(n=8)$ & & \multicolumn{4}{c}{$2.23 \pm 0.13$} \\
Control group $(n=32)$ & $3.48 \pm 0.17^{*}$ & $3.14 \pm 0.20^{*}$ & $2.47 \pm 0.11$ & $2.81 \pm 0.11^{*}$ \\
Lovastatin, $0.1 \mathrm{mg} / \mathrm{kg}(n=2)$ & $3.41 \pm 0.19^{*}$ & $3.20 \pm 0.18^{*}$ & $2.63 \pm 0.08^{*}$ & $2.56 \pm 0.12$ \\
Lovastatin, $1.0 \mathrm{mg} / \mathrm{kg}(n=32)$ & $3.70 \pm 0.21^{*}$ & $3.10 \pm 0.21^{*}$ & $2.56 \pm 0.11$ & $2.88 \pm 0.15^{*}$ \\
Lovastatin, $5.0 \mathrm{mg} / \mathrm{kg}(n=32)$ & $3.61 \pm 0.17^{*}$ & $3.33 \pm 0.22^{*}$ & $2.47 \pm 0.12$ & $2.59 \pm 0.10^{*, \#}$ \\
LCCN $(n=32)$ & $3.21 \pm 0.14^{*}$ & $2.69 \pm 0.14^{*, \dagger}$ & $2.51 \pm 0.12$ & $2.40 \pm 0.16$ \\
\hline
\end{tabular}

Note. Significant difference $(P<0.05)$ compared to: ${ }^{*}$ intact rats, ${ }^{*}$ rats receiving lovastatin at the dose of $1.0 \mathrm{mg} / \mathrm{kg},{ }^{\dagger}$ rats receiving lovastatin at the dose of $5.0 \mathrm{mg} / \mathrm{kg}$. LCCN - lovastatin-containing chitosan nanoparticles. Calcium concentration $-\mathrm{mmol} / \mathrm{l}$

Ta ble 2. Phosphorus concentration ( $\mathrm{mmol} / \mathrm{l}$ ) in serum of rats with bone defect and correction with lovastatin alone or $L C C N(M \pm m)$

\begin{tabular}{l|c|c|c|c}
\hline \multirow{2}{*}{\multicolumn{1}{c|}{ Group }} & \multicolumn{4}{c}{ Day of experiment } \\
\cline { 2 - 5 } & $3^{\text {rd }}$ & $7^{\text {th }}$ & $14^{\text {th }}$ & $28^{\text {th }}$ \\
\hline Intact rats $(n=8)$ & \multicolumn{4}{c}{$1.81 \pm 0.10$} \\
Control group $(n=32)$ & $2.62 \pm 0.12^{*}$ & $2.31 \pm 0.1^{*}$ & $1.89 \pm 0.12$ & $2.04 \pm 0.14$ \\
Lovastatin, $0.1 \mathrm{mg} / \mathrm{kg}(n=2)$ & $2.47 \pm 0.12^{*}$ & $2.21 \pm 0.12^{*}$ & $2.11 \pm 0.12$ & $2.01 \pm 0.14$ \\
Lovastatin, $1.0 \mathrm{mg} / \mathrm{kg}(n=32)$ & $2.71 \pm 0.15^{*}$ & $2.38 \pm 0.20^{*}$ & $2.19 \pm 0.10^{* *}$ & $2.19 \pm 0.14$ \\
Lovastatin, $5.0 \mathrm{mg} / \mathrm{kg}(n=32)$ & $2.73 \pm 0.13^{*}$ & $2.39 \pm 0.14^{*}$ & $2.00 \pm 0.11$ & $2.20 \pm 0.17$ \\
LCCN $(n=32)$ & $2.64 \pm 0.11^{*}$ & $1.91 \pm 0.12^{* *,+}$ & $2.01 \pm 0.15$ & $1.77 \pm 0.11$ \\
\hline
\end{tabular}

Note. Significant difference $(P<0.05)$ compared to: $*$ intact rats, ${ }^{* *}$ control group, ${ }^{\dagger}$ rats receiving lovastatin at the dose of $5.0 \mathrm{mg} / \mathrm{kg}$. LCCN - lovastatin-containing chitosan nanoparticles. Phosphorus concentration - mmol/l

cause of the tight balance and correlation between $\mathrm{Ca}$ and $\mathrm{P}$ metabolism.

The ALP activity is considered an indicator of osteoblast cell activity and the formation of new bone, while ACP has been used as a serum marker of bone resorption. We found that ALP activity was increased in the control group on the $3^{\text {rd }}$ (by $46.3 \%$, $P<0.05$ ) and $7^{\text {th }}$ (by 34,7 \%, $P<0.05$ ) days after the bone defect compared to intact rats (Fig. 2). Administration of lovastatin alone did not result in any significant changes compared to untreated rats (control group). At the same time, administration of LCCN led to the significant increase in ALP activity compared to untreated rats on the $14^{\text {th }}$ (by $46.3 \%$, $P<0.05$ ) and $28^{\text {th }}$ (by $26.9 \%, P<0.05$ ) days of the experiment. Moreover, in the groups of animals treated with LCCN, the ALP activity was higher in comparison with animals treated with some doses of lovastatin only on the $7^{\text {th }}, 14^{\text {th }}$ and $28^{\text {th }}$ days after the bone defect was made. These findings could be evidence of more intensive bone repair processes under the effect of LCCN compared to the effect of lovastatin alone.

Bone defect resulted in the marked increase of the serum ACP activity on the $3^{\text {rd }}$ day of the experiment (by $74.4 \%, P<0.05$ compared to intact rats). It should be noted that LCCN or the common pharmaceutical formulation of lovastatin did not significantly affect ACP activity in comparison to the control group.

In the next stages, this parameter gradually decreased in untreated animals and on the $28^{\text {th }}$ day it already did not differ significantly from the intact rats. Only the highest dose $(5.0 \mathrm{mg} / \mathrm{kg}$ ) of lovastatin alone on the $14^{\text {th }}$ day resulted in the significant decrease of serum ACP activity compared to control group animals. On the $14^{\text {th }}$ day the administration of LCCN resulted in a significant decrease of ACP activity in comparison with rats treated with lovastatin alone (Fig. 3). 


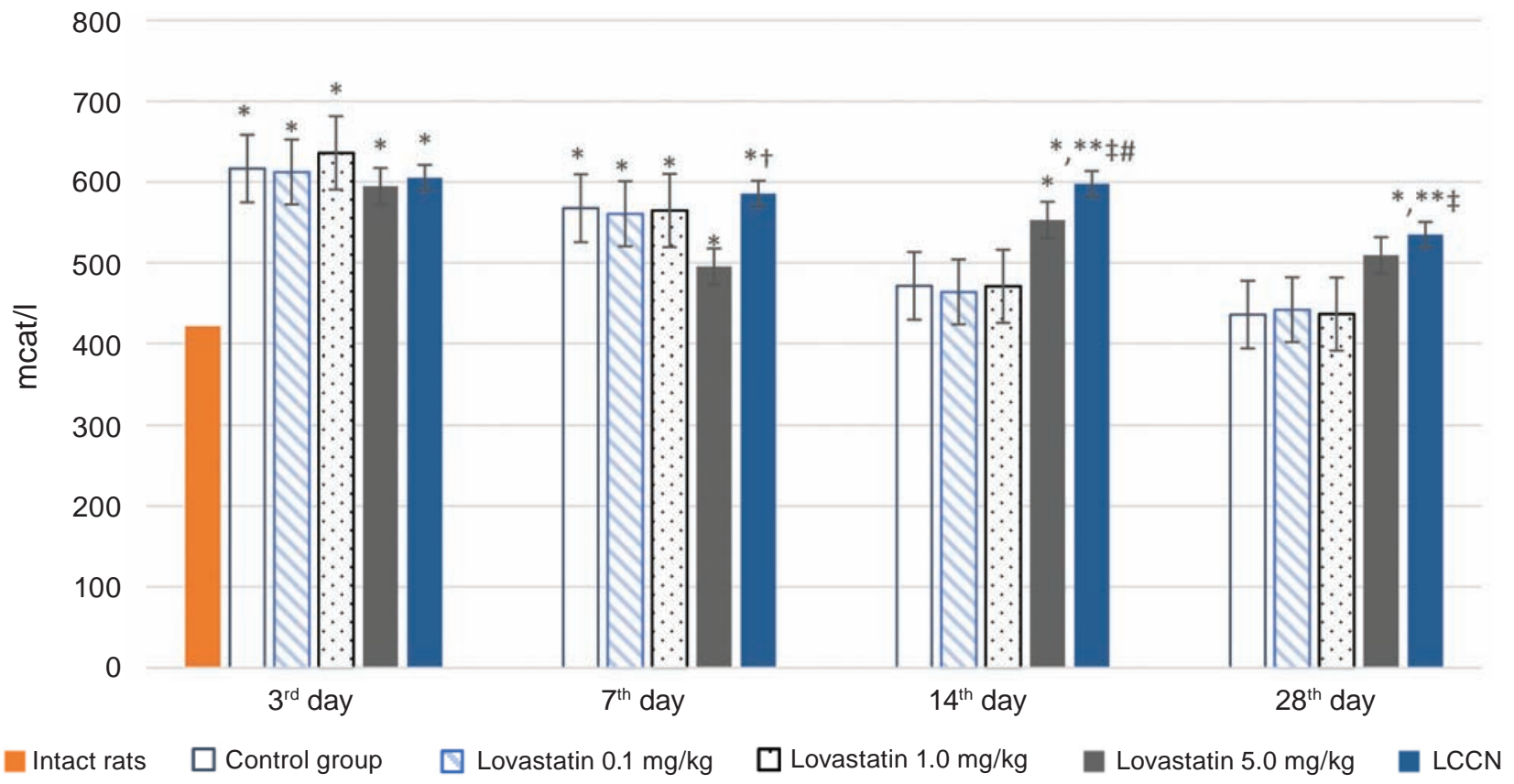

Fig. 2. ALP activity (mcat/l, $M \pm m$ ) in serum of rats with bone defect treated with lovastatin alone or LCCN. Significant difference $(P<0.05)$ compared to: *intact rats, **control group, ${ }^{*}$ rats receiving lovastatin at the dose of $0.1 \mathrm{mg} / \mathrm{kg}$, ${ }^{*}$ rats receiving lovastatin at the dose of $1.0 \mathrm{mg} / \mathrm{kg},{ }^{+}$rats receiving lovastatin at the dose of $5.0 \mathrm{mg} / \mathrm{kg}$. ALP - alkaline phosphatase; LCCN - lovastatin-containing chitosan nanoparticles; mcat - microkatal

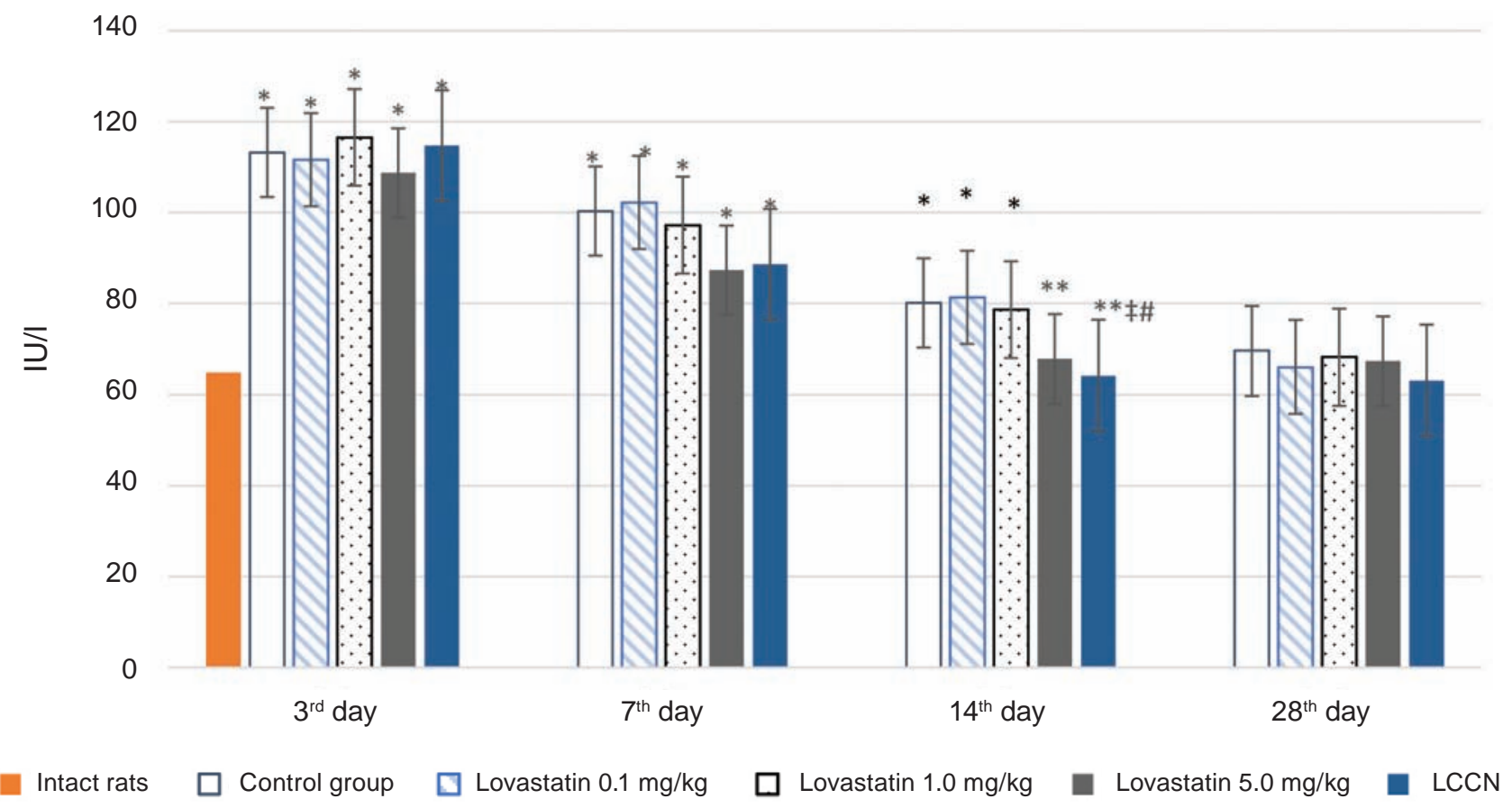

Fig. 3. ACP activity (IU/l, $M \pm m$ ) in serum of rats with bone defect treated with lovastatin alone or LCCN. Significant difference $(P<0.05)$ compared to: *intact rats, **control group, ${ }^{\ddagger}$ rats receiving lovastatin at the dose of $0.1 \mathrm{mg} / \mathrm{kg}$, " rats receiving lovastatin at the dose of $1.0 \mathrm{mg} / \mathrm{kg}$. ACP - acidic phosphatase; IU - international units; LCCN - lovastatin-containing chitosan nanoparticles 
Table 3. Mineralization index in rats with bone defect and correction with lovastatin alone or LCCN $(M \pm m)$

\begin{tabular}{l|c|c|c|c}
\hline \multirow{2}{*}{\multicolumn{1}{c|}{ Group }} & \multicolumn{4}{c}{ Day of experiment } \\
\cline { 2 - 5 } & $3^{\text {rd }}$ & $7^{\text {th }}$ & \multicolumn{1}{c}{$14^{\text {th }}$} & $28^{\text {th }}$ \\
\hline Intact rats $(n=8)$ & & \multicolumn{4}{c}{$6.63 \pm 0.37$} \\
Control group $(n=32)$ & $5.66 \pm 0.52$ & $5.87 \pm 0.50$ & $6.02 \pm 0.39$ & $6.50 \pm 0.54$ \\
Lovastatin, 0.1 mg/kg $(n=2)$ & $5.55 \pm 0.37$ & $5.60 \pm 0.38$ & $5.80 \pm 0.27$ & $6.89 \pm 0.48$ \\
Lovastatin, $1.0 \mathrm{mg} / \mathrm{kg}(n=32)$ & $5.52 \pm 0.17^{*}$ & $6.11 \pm 0.55$ & $6.11 \pm 0.38$ & $6.47 \pm 0.30$ \\
Lovastatin, $5.0 \mathrm{mg} / \mathrm{kg}(n=32)$ & $5.67 \pm 0.49$ & $5.95 \pm 0.60$ & $8.59 \pm 0.83^{*}$ & $7.66 \pm 0.36^{*}$ \\
LCCN $(n=32)$ & $5.31 \pm 0.17^{*}$ & $6.73 \pm 0.41$ & $9.38 \pm 0.37^{* * * * \neq \#}$ & $8.70 \pm 0.69^{*, * * *}$ \\
\hline
\end{tabular}

Note. Significant difference $(P<0.05)$ compared to: $*$ intact rats, ${ }^{* *}$ control group, ${ }^{*}$ rats receiving lovastatin at the dose of $0.1 \mathrm{mg} / \mathrm{kg}$, "rats receiving lovastatin at the dose of $1.0 \mathrm{mg} / \mathrm{kg}$. LCCN - lovastatin-containing chitosan nanoparticles

Based on the indices of the phosphatase activities (ALP, ACP) the MI was calculated (Table 3). Bone defect did not significantly change the ratio between ALP and ACP activities in experimental groups compared to intact rats. The high dose of lovastatin $(5.0 \mathrm{mg} / \mathrm{kg})$ increased this parameter on the $14^{\text {th }}$ and $28^{\text {th }}$ days in comparison with intact rats but not with the untreated group of animals. Instead, the long-term administration (for 14 and 28 days) of LCCN led to significant increases in the MI compared to both intact and control rats. Moreover, longterm administration of LCCN increased MI more effectively than low doses of lovastatin alone.

Collagenolytic activity reflects metabolic processes in connective tissue. On the $3^{\text {rd }}$ day it increased by $58.1 \%$ in the control group $(P<0.05)$ as well as in groups of rats that received lovastatin in doses of $0.1 \mathrm{mg} / \mathrm{kg}$ (by $52.4 \%$ ), $1.0 \mathrm{mg} / \mathrm{kg}$ (by $69.3 \%$ ) and $5.0 \mathrm{mg} / \mathrm{kg}$ (by 37.6\%) compared to intact animals (Fig. 4).

Rats administered LCCN showed significantly lower collagenolytic activity on the $3^{\text {rd }}$ and $7^{\text {th }}$ days of the experiment in comparison with both the control group and lovastatin treated groups. On the $7^{\text {th }}$ and $28^{\text {th }}$ days this parameter was insignificantly different in all experimental groups compared with intact rats.

The serum sialic acid concentration is a biochemical marker which characterizes the intensity of inflammatory and destructive processes in connective tissue and is also a valuable criterion for diagnostic evaluation of bone tissue status. We observed the marked increase of this parameter in the early stages (on the $3^{\text {rd }}$ day it was higher by $46.6 \%$ and on the $7^{\text {th }}$ day by $38.0 \%$ compared to the intact group) of the bone regenerative process. Lovastatin in a dose of $5.0 \mathrm{mg} / \mathrm{kg}$ injected for 7 days decreased the serum sialic acid level in rats with bone defect. Administration of LCCN for 7 days decreased the sialic acid concentration compared to both control rats and rats treated with lovastatin alone (Fig. 5). This finding could be evidence of suppression of the inflammation cascade reaction by lovastatin and especially by LCCN in this time frame after the bone defect formation. On the $14^{\text {th }}$ and $28^{\text {th }}$ days there were no significant differences in sialic acid levels among the experimental groups.

Histological examination of bone repair in the drill-hole model in rats demonstrated that the common pharmaceutical formulation of lovastatin has positive effects on bone remodeling only at the highest dose of $5.0 \mathrm{mg} / \mathrm{kg}$ (Fig. 6, c) compared to the control group of rats (Figs. 6, $a-b$ ). We observed the decrease of blood thrombi size on the $7^{\text {th }}$ day. From the $14^{\text {th }}$ day blood thrombi were substituted by fibrous-reticular tissue, and loose connective tissue with osteocytes was formed up to the $28^{\text {th }}$ day. The most pronounced effect was observed with the administration of LCCN (Fig. 6, $d$ ). In this group of rats, granulations were formed on the $7^{\text {th }}$ day. On the $14^{\text {th }}$ day granulations were substituted by fibrousreticular tissue, and on the $28^{\text {th }}$ day dense connective tissue occurred at the site of the bone defect.

The diameter of the bone defect and the bone mineral density were studied on the $14^{\text {th }}$ and $28^{\text {th }}$ days of the experiment by CT examination. Radiographic dynamics of bone defect closure reflects the speed of post-traumatic regeneration. While bone mineral density is proportional to bone robustness and characterized the biochemical features of the callus. CT evaluation demonstrated that lovastatin administration at the doses of 0.1 and $1.0 \mathrm{mg} / \mathrm{kg}$ did not promote bone defect repair. Only the highest 


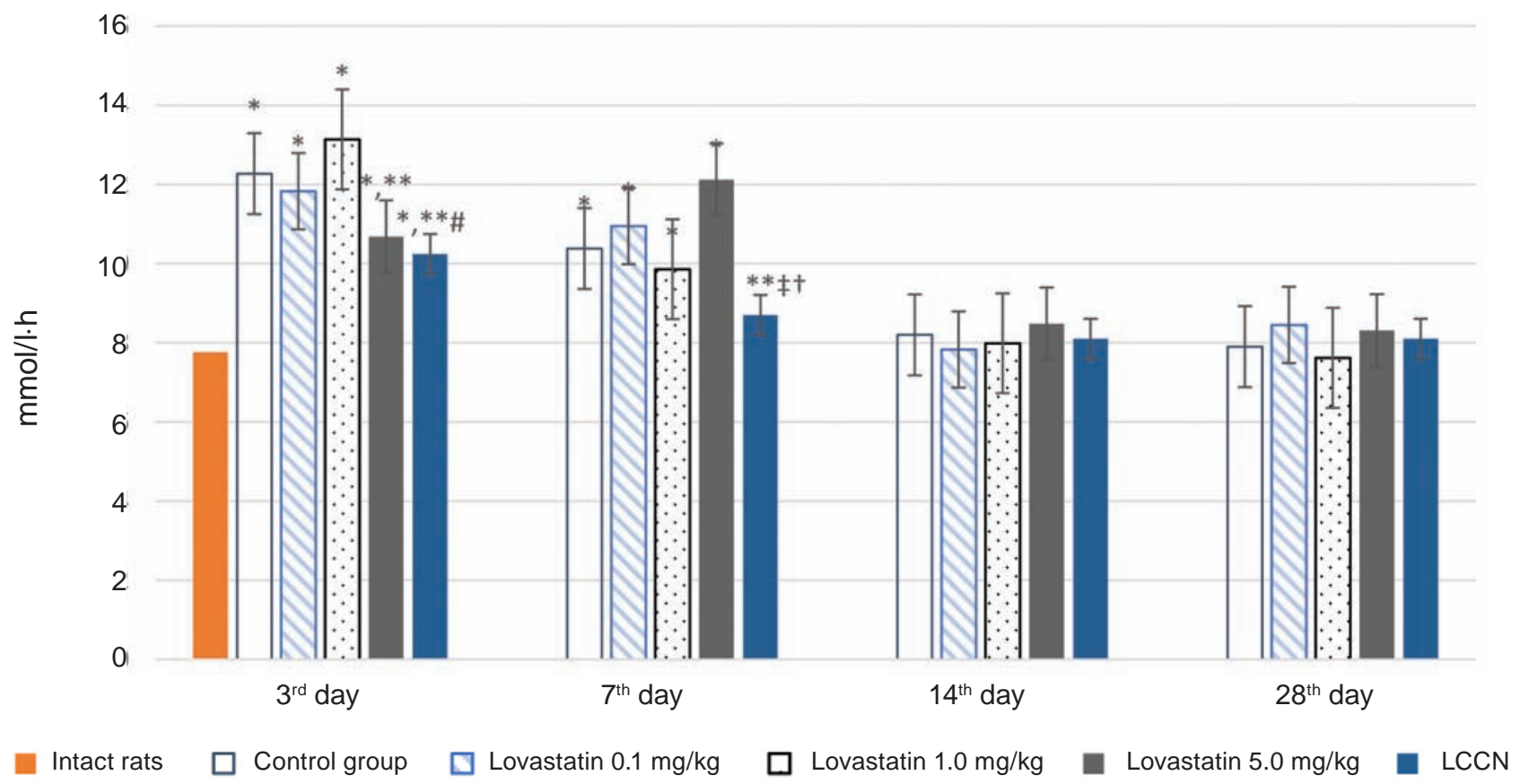

Fig. 4. Collagenolytic activity in blood plasma (mmol/l.h, $M \pm m)$ of rats with bone defect and correction with lovastatin alone or LCCN. Significant difference $(P<0.05)$ compared to: *intact rats, ** control group, ${ }^{*}$ rats receiving lovastatin at the dose of $0.1 \mathrm{mg} / \mathrm{kg}$, ${ }^{\text {}}$ rats receiving lovastatin at the dose of $1.0 \mathrm{mg} / \mathrm{kg},{ }^{\dagger}$ rats receiving lovastatin at the dose of $5.0 \mathrm{mg} / \mathrm{kg}$. LCCN - lovastatin-containing chitosan nanoparticles

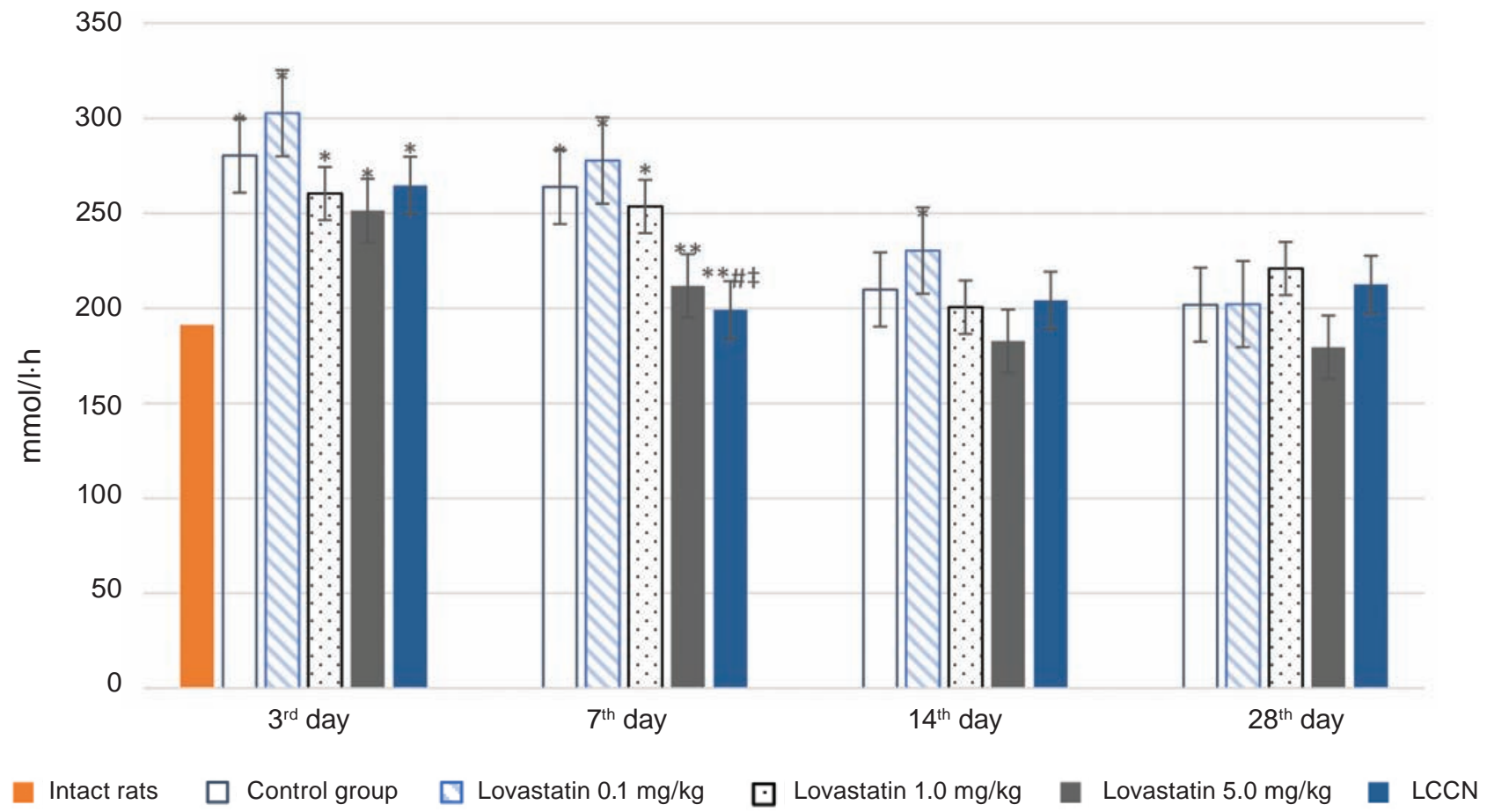

Fig. 5. Sialic acid concentration ( $\mathrm{mmol} / \mathrm{l} \cdot \mathrm{h}, M \pm \mathrm{m}$ ) in blood plasma of rats with bone defect and correction with lovastatin alone or LCCN. Note. Significant difference $(P<0.05)$ compared to: *intact rats, ${ }^{* *}$ control group, ${ }^{*}$ rats receiving lovastatin at the dose of $0.1 \mathrm{mg} / \mathrm{kg}$, ${ }^{*}$ rats receiving lovastatin at the dose of $1.0 \mathrm{mg} / \mathrm{kg}$. LCCN - lovastatin-containing chitosan nanoparticles 

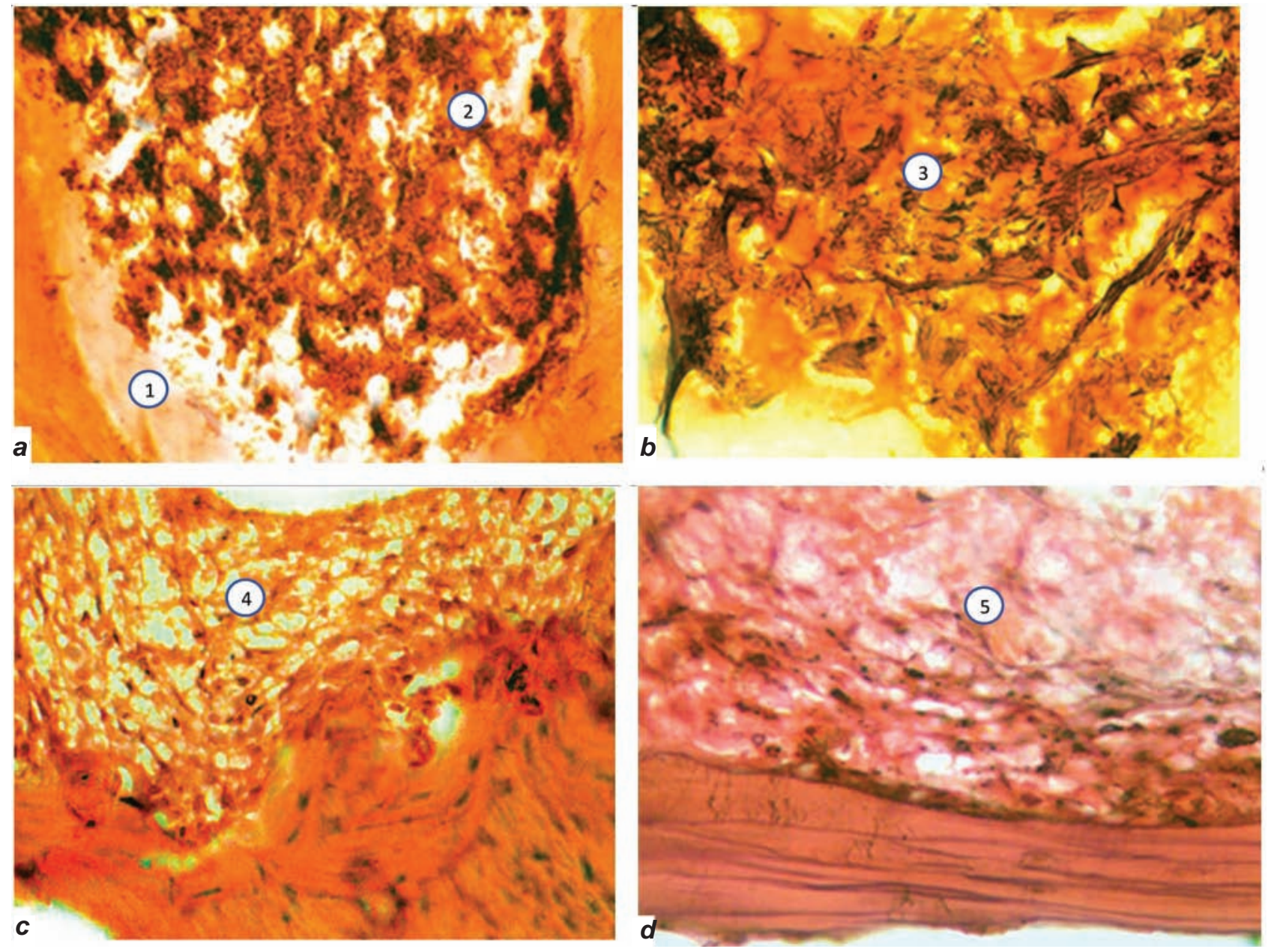

Fig. 6. Histology of tibia with defect in rats of the control group on the $3^{\text {rd }}(\boldsymbol{a})$ and $28^{\text {th }}$ (b) day, rats treated with lovastatin at the dose of $5.0 \mathrm{mg} / \mathrm{kg}$ (c) and LCCN (d) on the $28^{\text {th }}$ day. 1 - damaged bone, 2 - blood thrombi at the site of the bone defect, 3 - fibrous-reticular tissue, 4 -loose connective tissue, 5 -dense connective tissue. Hematoxylin and Eosin (H\&E). $\boldsymbol{a}: \times 100 ; \boldsymbol{b}, \boldsymbol{c}, \boldsymbol{d}: \times 200$. LCCN - lovastatin-containing chitosan nanoparticles

dose of lovastatin $(5.0 \mathrm{mg} / \mathrm{kg})$ and LCCN promoted partial closure of the defect and increased bone mineral density compared with the control.

Originally, the diameter of the drill-hole was 2 $\mathrm{mm}$. It is known that bone defect closure starts at the stage of osteoregeneration (bone formation). That is why CT examinations were performed on the $14^{\text {th }}$ and $28^{\text {th }}$ days of the experiment. On the $14^{\text {th }}$ day in untreated rats, the diameter was $2.04 \pm 0.03 \mathrm{~mm}$ (Fig. 7, a), and in rats treated with lovastatin at the doses of 0.1 and $1.0 \mathrm{mg} / \mathrm{kg}$ it was even larger: $2.11 \pm 0.14$ and $2.18 \pm 0.29 \mathrm{~mm}$, respectively. The enlargement may be due to a predominance of the processes of bone destruction. Lovastatin at the dose of $5.0 \mathrm{mg} / \mathrm{kg}$ resulted in a decrease of the hole size to $1.78 \pm 0.15 \mathrm{~mm}$, a $12.7 \%$ reduction compared to the control group. On the $14^{\text {th }}$ day, LCCN shrank the hole diameter to
$1.68 \pm 0.15 \mathrm{~mm}$ (reductions of $17.6 \%$ compared to the control group and $20.4 \%$ compared to rats treated with $0.1 \mathrm{mg} / \mathrm{kg}$ lovastatin).

The diameter of the drill-hole in the control group was $1.42 \pm 0.2 \mathrm{~mm}$ on the $28^{\text {th }}$ day of the experiment. Lovastatin administration promoted full closure of the defect in 1/3-1/2 of rats at the doses of 0.1 and $1.0 \mathrm{mg} / \mathrm{kg}$, while the dose of $5.0 \mathrm{mg} / \mathrm{kg}$ led to the closure of the hole in all animals (Fig. 7, b). In the case of LCCN administration, the complete closure of the bone defect was also accompanied by increased bone density (Fig. 7, c).

Bone tissue regeneration is a booming area of investigation and involves diverse scientific fields (e.g., cell signaling, biomaterial sciences) to meet the demands for bone repair. Many challenges regarding the application of statins in bone healing remained 

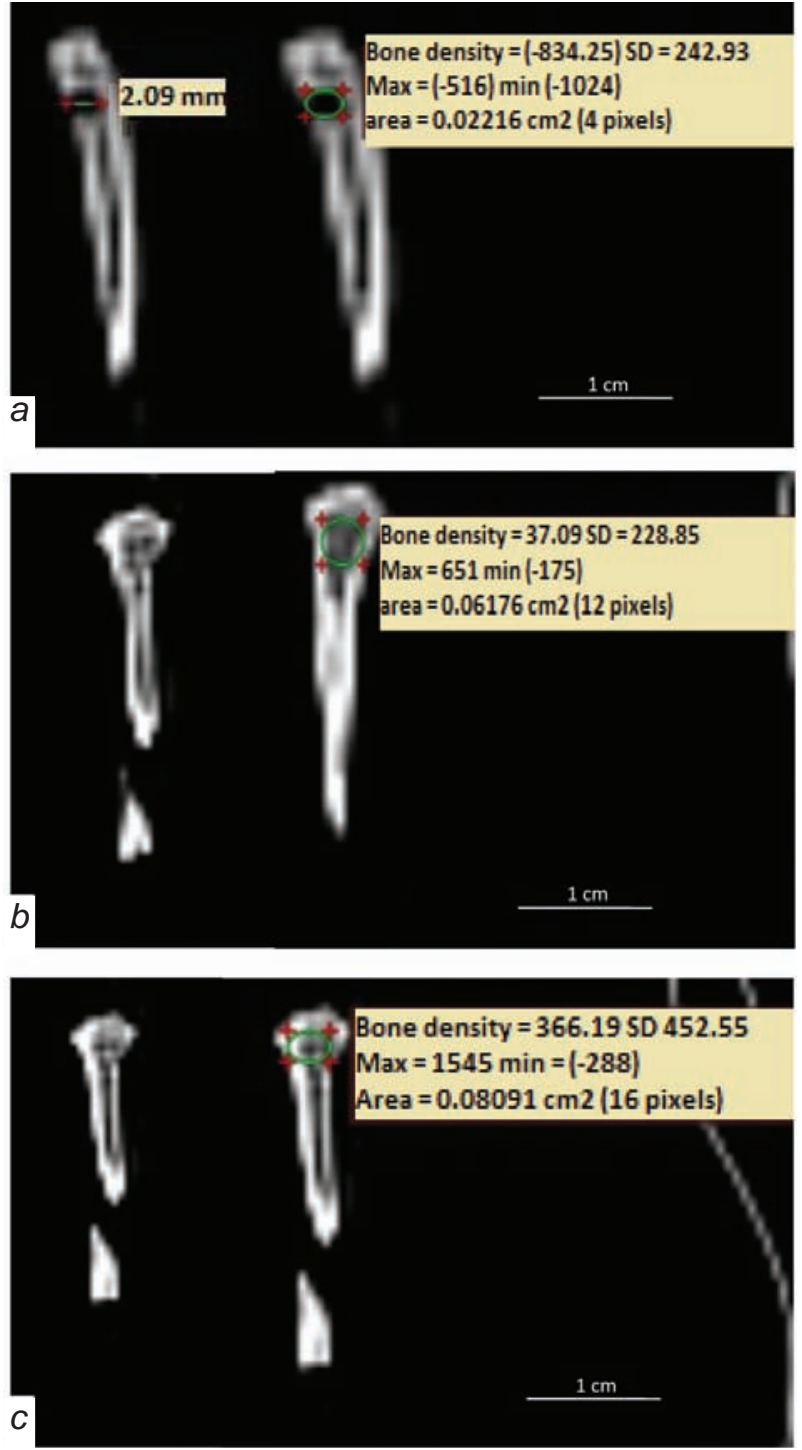

Fig. 7. Computed tomography (CT) of tibia of the control group rats on the $14^{\text {th }}$ day (a), rats treated with lovastatin at the dose of $5.0 \mathrm{mg} / \mathrm{kg}$ on the $28^{\text {th }}$ day (b), and rats treated with LCCN on the $28^{\text {th }}$ day (c). LCCN - lovastatin-containing chitosan nanoparticles

unanswered. A large number of factors could impact bone repair: systemic factors such as age, nutrition, physical activity, endocrine pathology (diabetes mellitus, thyroid gland function), obesity and other concomitant pathology; some medical agents (NSAIDs); hypovitaminosis of A, C, D, and E; immune response of the body; traumatic CNS injury; alcohol consumption, smoking; and local factors such as infectious complications, incorrect repositioning, poor local blood circulation, and peripheral neuropathy [34-36].
One of the strategies to increase the efficacy of bone regeneration via increasing the number of osteoblasts or their maturation is targeting molecular signaling pathways, in particular the pathway resulting in hyperexpression of BMPs (e.g., BMP-2, BMP-3, BMP-4 and BMP-7) [4, 5]. However, administration of BMPs may produce side effects and is very expensive [8]. It has been shown that statins can increase BMP expression by bone cells [9-11], but the results of studies that investigated the effect of statins on bone repair are ambiguous [21, 37, 38]. These findings could be explained by the extensive liver metabolism of this class of drugs, which leads to a critically low concentration of statins in bone tissue after oral or intravenous administration. A potential solution for this problem could be the development of a delivery system for statins that transfers them directly to the site of the bone defect. Polymeric nanoparticles are the most appropriate for this purpose because of their excellent pharmaceutical properties such as high entrapment efficiency, controlled release rates, and reduced enzymatic degradation [39, 40]. Among various polymers, chitosan has attracted remarkable attention for its use in preparing polymer nanoparticles because it has mucoadhesive properties and it enhances tissue penetration through disruption of intercellular tight junctions [40-42]. Chitosan is a linear cationic heteropolymer composed of $\mathrm{N}$-acetylglucosamine and $\beta$-1,4-linked glucosamine residues. It was found that it is the most similar to glycosaminoglycans, biocompatible and biodegradable, and produces a minimal immune response. It can be easily processed into drug delivery systems [26-28]. Therefore, it is highly desirable to synthesize biocomposite materials for the enhancement of tissue regeneration properties. The low cost and relatively good safety profile are the basis for new applications of statins. Lovastatin used to treat hypercholesterolemia also demonstrates anabolic actions on bone through the stimulation of BMP-2 expression. The exact mechanism of action may be realized not only via its activity on HMG-CoA reductase in the mevalonate pathway, as some authors have supposed [8-10]. Statins may also antagonize osteoclasts by increasing expression of osteoprotegerin, thereby influencing the receptor activator of the NF- $\kappa$ B ligand (RANKL)-osteoprotegerin (OPG) pathway. Lovastatin is a natural statin which can be used to treat various diseases including atherosclerosis, sepsis, peripheral arterial disease, ischemic disease and bone fracture. It was reported that a 
high dose of statin given orally to femoral-fractured mice promoted fracture healing [43]. However, statin given orally at a cholesterol-lowering dose does not reach the bones very well and only a minor fraction reaches the fracture site, so a high oral dose is required to achieve sufficient concentration of statin at the bone fracture site. However, high doses of statin can cause adverse effects such as liver failure, kidney disease and rhabdomyolysis. In order to achieve sufficient statin concentration at the fracture site without using high doses, it needs to be delivered directly to the fracture site. We incorporated lovastatin into chitosan nanoparticles and found that administration of this pharmaceutical formulation enhances fracture repair in a preclinical bone defect model more effectively than administration of lovastatin alone. We have shown that when delivered this way, lovastatin accelerated the healing rate and improved the histological characteristics of the bone at the defect site. It is worth noting that the minimal therapeutic dose of lovastatin $(0.1 \mathrm{mg} / \mathrm{kg})$ administered in the form of nanoparticles showed the higher radiographic score, the smaller defect gap, and better histological characteristics in comparison with the 50 times higher dose of lovastatin alone $(5.0 \mathrm{mg} / \mathrm{kg})$.

As far as limitations of this study, it should be noted that we did not monitor the kidney function of experimental rats and did not do comparative analysis concerning the risks factors which could affect bone repair outcomes.

The present study showed that these agents were effective in improving osteoporotic fracture healing when administered with a targeted delivery system. Earlier results of combined targeted deliveries of tocotrienol and lovastatin showed improvement in mineralization and strength of callus formed during fracture healing of osteoporotic bone [15]. Using this delivery system, low doses of the agents are combined with their suitable carriers and they are released slowly with a single injection to maintain high concentrations at the bone microenvironment.

Conclusion. Post-traumatic osteoregeneration is a complex cascade of biochemical and physiological reactions as a response to bone damage. Any interruption of these cascade processes could have negative impacts on bone repair. Our study showed the inexpediency of lovastatin use in therapeutic doses for bone repair. It was proposed that local application at fracture sites of chitosan nanoparticles loaded with lovastatin has promising potential for the treatment of bone fractures. Further randomized clinical trials with larger samples and histological studies are necessary to confirm its effect.

Conflict of interest. Conflict of interest. Authors have completed the Unified Conflicts of Interest form at http://ukrbiochemjournal.org/wp-content/ uploads/2018/12/coi_disclosure.pdf and declare no conflict of interest.

Funding. The study was performed as a part of the initiative research of TNMU "Biochemical mechanisms of toxicity of nanoparticles of different origin and other anthropogenic and biogenic toxicants in biological systems" (No 0112U000542).

\section{ЛОКАЛЬНЕ ЗАСТОСУВАННЯ ХІТОЗАНОВИХ НАНОЧАСТИНОК ІЗ ЛОВАСТАТИНОМ СПРИЯЕ РЕГЕНЕРАЦІї КІСТОК У ЩУРІВ}

\author{
О. О. Шевчук ${ }^{1 \rrbracket}$, Я. В. Панасюк², \\ M. М. Корда ${ }^{3}$
}

${ }^{1}$ Кафедра фармакології з клінічною фармакологією, Тернопільський національний медичний університет імені І. Я. Горбачевського, Тернопіль, Україна; ${ }^{2}$ Кафедра функціональної та лабораторної діагностики, Тернопільський національний медичний університет імені I. Я. Горбачевського, Тернопіль, Україна; ${ }^{3}$ Кафедра медичної біохімії, Тернопільський національний медичний університет імені

I. Я. Горбачевського, Тернопіль, Україна; 凶e-mail: shevchukoo@tdmu.edu.ua

Відомо, що статини прискорюють остеорегенерацію. Однак цей ефект спостерігається лише в разі значного збільшення їх терапевтичної дози або за їх введення шляхом інфузії, що $є$ неприйнятним для пацієнтів. Метою нашого дослідження було порівняння ефектів ловастатину в звичайній лікарській формі та хітозанових наночастинок, що містять ловастатин на відновлення кісткового дефекту в щурів. Дослідження проводили на білих нелінійних щурах, яких було розподілено на 4 групи: 1 - інтактні тварини; 2 тварини з післятравматичним кістковим дефектом без корекції (контрольна група); 3 - тварини, 3 кістковим дефектом, які отримували ловастатин у дозах $0,1,1,0$ та 5,0 мг/кг; 4 - тварини, які отримували хітозанові наночастинки 3 ловастатином (НЛВ) з розрахунку 0,1 мг/кг. Кістковий дефект моделювали в проксимальному відділі 
правої великогомілкової кістки за допомогою стоматологічного бора (2,0 мм в діаметрі) шляхом трансосальної перфорації. Щурів виводили 3 експерименту на 3-ю, 7-у, 14-у та 28-у добу після формування дефекту. У сироватці крові піддослідних тварин визначали концентрацію кальцію (Са), фосфору (Р), сіалових кислот, активність лужної та кислої фосфатаз, індекс мінералізації та колагенолітичну активність. Для візуалізації регенеративних процесів кістки проводили комп'ютерну томографію (КТ) та гістологічне дослідження. Встановлено, що застосування ловастатину в терапевтичних дозах (0,1 та 1,0 мг/кг) неефективне для відновлення кісткового дефекту. Лише високі дози препарату (5,0 мг/кг) сприяли остеорегенерації. Введення НЛВ перевищувало ефекти ловастатину в звичайній лікарській формі, про що свідчили результати КТ та вірогідні зміни показників $\mathrm{Ca}$, P, сіалових кислот і активність лужної та кислої фосфатаз, індекс мінералізації, колагенолітична активність. Показано, що хітозанові наночастинки $з$ ловастатином ефективно стимулюють загоєння переломів у щурів, що дає змогу припустити застосування такого підходу для посилення остеорегенерації в людей.

К л ючо в і слов а: хітозанові наночастинки, ловастатин, перелом, кісткова регенерація у щурів.

\section{References}

1. Majidinia M, Sadeghpour A, Yousefi B. The roles of signaling pathways in bone repair and regeneration. J Cell Physiol. 2018; 233(4): 29372948.

2. Einhorn TA, Gerstenfeld LC. Fracture healing: mechanisms and interventions. Nat Rev Rheumatol. 2015; 11(1): 45-54.

3. Marsell R, Einhorn TA. The biology of fracture healing. Injury. 2011; 42(6): 551-555.

4. Lopes D, Martins-Cruz C, Oliveira MB, Mano JF. Bone physiology as inspiration for tissue regenerative therapies. Biomaterials. 2018; 85: 240-275.

5. Martin V, Bettencourt A. Bone regeneration: Biomaterials as local delivery systems with improved osteoinductive properties. Mater Sci Eng C Mater Biol Appl. 2018; 82: 363-371.

6. Conway JD, Shabtai L, Bauernschub A, Specht SC. BMP-7 versus BMP-2 for the treatment of long bone nonunion. Orthopedics. 2014; 37(12): e1049-e1057.

7. von Rüden C, Morgenstern M, Hierholzer C, Hackl S, Gradinger FL, Woltmann A, Bühren V, Jan Friederichs J. The missing effect of human recombinant Bone Morphogenetic Proteins BMP-2 and BMP-7 in surgical treatment of aseptic forearm nonunion. Injury. 2016; 47(4): 919-924.

8. Gutierrez GE, Edwards JR, Garrett IR, Nyman JS, McCluskey B, Rossini G, Flores A, Neidre DB, Mundy GR. Transdermal lovastatin enhances fracture repair in rats. $J$ Bone Miner Res. 2008; 23(11): 1722-1730.

9. Ohnaka K, Shimod S, Nawata H, Shimokawa H, Kaibuchi K, Iwamoto Y, Takayanagi R. Pitavastatin enhanced BMP-2 and osteocalcin expression by inhibition of Rho-associated kinase in human osteoblasts. Biochem Biophys Res Commun. 2001; 287(2): 337-342.

10. Yamashita M, Otsuka F, Mukai T, Otani H, Inagaki K, Miyoshi T, Goto J, Yamamura M, Makino H. Simvastatin antagonizes tumor necrosis factor-alpha inhibition of bone morphogenetic proteins-2-induced osteoblast differentiation by regulating Smad signaling and Ras/Rho-mitogen-activated protein kinase pathway. J Endocrinol. 2008; 196(3): 601-613.

11. Shah SR, Werlang CA, Kasper FK, Mikos AG. Novel applications of statins for bone regeneration. Natl Sci Rev. 2015; 2(1): 85-99.

12. Horiuchi N, Maeda T. Statins and bone metabolism. Oral Dis. 2006; 12(2): 85-101.

13. Ibrahim N, Mohamed N, Shuid AN. Update on statins: hope for osteoporotic fracture healing treatment. Curr Drug Targets. 2013; 14(13): 1524-1532.

14. Hagihara M, Endo M, Hata K, Higuchi C, Takaoka K, Yoshikawa H, Yamashita T. Neogenin, a receptor for bone morphogenetic proteins. J Biol Chem. 2011; 286(7): 5157-5165.

15. Ibrahim N, Mohamed N, Soelaiman IN, Shuid AN. The Effects of Targeted Deliveries of Lovastatin and Tocotrienol on OssificationRelated Gene Expressions in Fracture Healing in an Osteoporosis Rat Model. Int J Environ Res Public Health. 2015; 12(10): 12958-12976.

16. Gutierrez GE, Lalka D, Garrett IR, Rossini G, Mundy GR. Transdermal application of lovastatin to rats causes profound increases in bone formation and plasma concentrations. Osteoporos Int. 2006; 17(7): 1033-1042. 
17. Jadhav SB, Narayana Murthy PS, Singh MM, Jain GK. Distribution of lovastatin to bone and its effect on bone turnover in rats. J Pharm Pharmacol. 2006; 58(11): 1451-1458.

18. Perazella MA, Izzedine H. New drug toxicities in the onco-nephrology world. Kidney Int. 2015; 87(5): 909-917.

19. Shahrezaee M, Oryan A, Bastami F, Hosseinpour S, Shahrezaee MH, Kamali A. Comparative impact of systemic delivery of atorvastatin, simvastatin, and lovastatin on bone mineral density of the ovariectomized rats. Endocrine. 2018; 60(1): 138-150.

20. Dodiya H, Kale V, Goswami S, Sundar R, Jain M. Evaluation of adverse effects of lisinopril and rosuvastatin on hematological and biochemical analytes in wistar rats. Toxicol Int. 2013; 20(2): 170-176.

21. Encarnação IC, Xavier CC, Bobinski F, dos Santos AR, Corrêa M, de Freitas SF, Aragonez A, Goldfeder EM, Cordeiro MM. Analysis of bone repair and inflammatory process caused by simvastatin combined with PLGA+HA+ $\beta$ TCP scaffold. Implant Dent. 2016; 25(1): 140-148.

22. Wu Y, Yang W, Wang C, Hu J, Fu S. Chitosan nanoparticles as a novel delivery system for ammonium glycyrrhizinate. Int J Pharm. 2005; 295(1-2): 235-245.

23. Saeed RM, Dmour I, Taha MO. Stable chitosanbased nanoparticles using polyphosphoric acid or hexametaphosphate for tandem ionotropic/ covalent crosslinking and subsequent investigation as novel vehicles for drug delivery. Front Bioeng Biotechnol. 2020; 8: 4.

24. Li SW, Song HP, Leng Y. Rapid determination of lovastatin in the fermentation broth of Aspergillus terreus using dual-wavelength UV spectrophotometry. Pharm Biol. 2014; 52(1): 129-135.

25. Laçin N, İzol BS, Özkorkmaz EG, Deveci B, Tuncer MC. The effect of graft application and simvastatin treatment on tibial bone defect in rats. A histological and immunohistochemical study. Acta Cir Bras. 2019; 34(4): e201900408.

26. Wei L, Yu D, Wang M, Deng L, Wu G, Liu Y. Dose effects of slow-released bone morphogenetic protein-2 functionalized $\beta$-tricalcium phosphate in repairing critical-sized bone defects. Tissue Eng Part A. 2020; 26(3-4): 120-129.

27. Toker H, Ozdemir H, Ozer H, Eren K. Alendronate enhances osseous healing in a rat calvarial defect model. Arch Oral Biol. 2012; 57(11): 1545-1550.

28. Sharaev PN, Pishkov VN, Zvorygina NG, Shinkareva LF, Napol'skikh VM. Determination of the collagenolytic activity of blood plasma. Lab Delo. 1987; (1): 60-62. (In Russian).

29. Kolb VH, Kamyshnikov VS. Clinical Biochemistry. Minsk: Belarus, 1976. 311 p.

30. Sharaev PN, Pishkov VN, Solov'ev NI, Shirokova TIu, Solov'eva TV. Method of determining glycosaminoglycans in biological fluids. Lab Delo. 1987; (5): 330-332. (In Russian).

31. Kalahasthi R, Barman T, Shankara Bagepally BS. Assessment of bone turnover biomarkers in lead-battery workers with long-term exposure to lead. Int J Occup Environ Med. 2020; 11(3): 140-147.

32. Shcherba V, Kyryliv M, Bekus I, Krynytska I, Marushchak M, Korda M. A comparative study of connective tissue metabolism indices in experimental comorbidity-free periodontitis and periodontitis combined with thyroid dysfunction. J Med Life. 2020; 13(2): 219-224.

33. Williams C, Sapra A. Osteoporosis Markers, http://www.ncbi.nlm.nih.gov/pubmed/32644732 (2020, accessed 14 February 2021).

34. Lisowska B, Kosson D, Domaracka K. Positives and negatives of nonsteroidal anti-inflammatory drugs in bone healing: the effects of these drugs on bone repair. Drug Des Devel Ther. 2018; 12: 1809-1814.

35. Sathyendra V, Darowish M. Basic science of bone healing. Hand Clin. 2013; 29(4): 473-481.

36. Hernandez RK, Do TP, Critchlow CW, Dent RE, Jick SS. Patient-related risk factors for fracturehealing complications in the United Kingdom General Practice Research Database. Acta Orthop. 2012; 83(6): 653-660.

37. Li Y, Zhang Z, Zhang Z. Porous chitosan/ nano-hydroxyapatite composite scaffolds incorporating simvastatin-loaded PLGA microspheres for bone repair. Cells Tissues Organs. 2018; 205(1): 20-31.

38. Tahamtan S, Shirban F, Bagherniya M, Johnston TP, Sahebkar A. The effects of statins on dental and oral health: a review of preclinical and clinical studies. J Transl Med. 2020; 18(1): 155.

39. Wu X, Pricev, Guy RH. Disposition of nanoparticles and an associated lipophilic permeant following topical application to the skin. $\mathrm{Mol}$ Pharm. 2009; 6(5): 1441-1448. 
40. Hussain Z, Katas H, Mohd Amin MC, umolosasi E, Buang F, Sahudin S. Self-assembled polymeric nanoparticles for percutaneous codelivery of hydrocortisone/hydroxytyrosol: an ex vivo and in vivo study using an NC/Nga mouse model. Int J Pharm. 2013; 444(1-2): 109119.

41. He W, Guo X, Zhang M. Transdermal permeation enhancement of N-trimethyl chitosan for testosterone. Int J Pharm. 2008; 356(1-2): 82-87.
42. Abinaya B, Prasith TP, Ashwin B, Viji Chandran S, Selvamurugan N. Chitosan in Surface Modification for Bone Tissue Engineering Applications. Biotechnol J. 2019; 14(12): e1900171.

43. Garrett IR, Gutierre GE, Rossini G, Nyman J, McCluskey B, Flores A, Mundy GR. Locally delivered lovastatin nanoparticles enhance fracture healing in rats. J Orthop Res. 2007; 25(10): 1351-1357. 